УДК 63

DOI $10.21661 / \mathrm{r}-553728$

Гришин E.A.

\title{
МОРФОБИОХИМИЧЕСКИЕ ПОКАЗАТЕЛИ
}

\section{И ПОКАЗАТЕЛИ БЕЛКОВОГО ОБМЕНА У МОЛОДНЯКА ГУСЕЙ, ПОТРЕБЛЯВШИХ ВИТАМИННУЮ ДОБАВКУ}

Аннотация: целью работы являлось изучение показателей белкового обмена и морфобиохимических показателей молодняка гусей при использовании кормовой добавки «Витаммин». Птииа контрольной группь получала основной рациион, 1 опытной-рацион с добавлением Витаммин в дозировке 0,2 мл/л воды; a 2 опытной - 0,5 мл/л воды. В результате проведенных исследований установлено, что использование кормовой добавки «Витаммин» для гусей способствовало более интенсивному обмену веществ, и как следствие лучшее снабжение кислородом органов и тканей, в сравнении со сверстниками из контроля. В опытных группах, при увеличении дозировки кормовой добавки у гусят отмечено повышение уровня тканевого дыхания, что характерно при увеличении обменных процессов и как следствие, повыщении продуктивности.

Ключевые слова: молодняк гусей, комбикорма, добавка «Витаммин», гематологические показатели, белковый обмен.

\section{Grishin E.A.}

\section{MORPHO-BIOCHEMICAL AND PROTEIN TURNOVER READINGS OF GROWING GEESE CONSUMING VITAMIN SUPPLEMENTS}

Abstract: the aim of the study was to examine the protein turnover and morphobiochemical readings of growing geese taking "Vitammin" feed additive. The control banding poultry received basic diet, the 1st experimental group received the diet with the addition of "Vitammin" in a dose of $0.2 \mathrm{ml} / \mathrm{l}$ of water, the 2nd experimental group - $0.5 \mathrm{ml} / \mathrm{l}$ of water. The research conducted showed that the use of "Vitammin" feed additive contributed to high-turnover rates and, consequently, improved the oxygen supply to organs and tissues in contrast to the control banding. In case of increasing 
the dose the additive it was noted that the rates of aerobic respiration increased as well, which is typical for the augmentation of metabolic processes and, subsequently, productivity.

Keywords: growing geese, combined feed, "Vitammin" feed additive, hematological reading, protein turnover.

«Современное птицеводство - одна из самых динамично развивающихся отраслей животноводства. Птица отличается интенсивным ростом, большой продуктивностью и хорошей оплатой корма. Разведение сельскохозяйственной птицы обеспечивает равномерное снабжение населения высокопитательными продуктами на протяжении года» [1]. Для обеспечения стабильного роста отрасли птицеводства необходимо увеличение продуктивности птицы, ее сохранности и качества получаемой продукции. Продуктивность птицы зависит от многих факторов - генетических, селекционной работы, условий кормления и содержания. «Необходимо поддержание продуктивности птицы, определяемой ее генетическим потенциалом» [2;3].

«Большое значение в вопросе увеличения продуктивности отводится кормлению птицы, которое необходимо балансировать по обменной энергии, питательным веществам, витаминам, минералам» [4; 5]. «Основными биологически активными веществами, необходимыми для жизнедеятельности организма птицы являются витамины. Их недостаток наносит существенный ущерб птицеводству, приводя к нарушению биохимических процессов и морфологическим изменениям в органах и тканях птицы» [6].

Обмен витаминов в организме не является стабильным и зависит от вида птицы, кросса, возраста, продуктивности, условий содержания, стресс-факторов, сочетания питательных веществ и витаминов в комбикормах и др. Каждый из этих факторов может изменять степень использования витаминов и влиять на зоотехнические показатели и иммунную систему организма птицы.

В связи с этим использование витаминной кормой добавки Витаммин для молодняка гусей является актуальным и имеет практическое значение. 
Целью работы являлось изучение гематологических показателей молодняка гусей при использовании кормовой добавки Витаммин.

Исследования выполнены на базе КФХ «Попов С.Н.» Шумихинского района, Курганской области. Для научно-хозяйственного опыта формировали группы птицы методом сбалансированных групп, с учетом возраста, живой массы, физиологического состояния. Опыт провели на 1500 гусятах, разделенных в 3 группы. В каждую группу было отобрано по 500 голов суточных гусят. Срок выращивания 60 суток. Молодняк гусей контрольной группы кормили с использованием комбикорма ПК-31 (с 1 по 3 неделю выращивания) и ПК-32 (с 4 по 9 неделю выращивания); 1 опытной дополнительно ввели добавку Витаммин в дозе 0,2 мл/л воды; а 2 опытной -0,5 мл/л воды. Кормление гусей проводили с учетом норм ВНИТИП. Условия содержания, плотность посадки, фронт кормления и поения, параметры микроклимата во всех группах были равные [7]. Полученный в опытах цифровой материал подвергли биометрической обработке с использованием программы Microsoft Excel [8]. Разницу считали достоверной при $\mathrm{P} \leq 0,05$.

В целях изучения морфологических и биохимических показателей крови у подопытного молодняка гусей, утром за час до кормления птицы была взята кровь из крыловой вены конце выращивания (в возрасте и 60 суток).

Морфобиохимические показатели крови подопытных гусят-бройлеров в различные возрастные периоды приведены в таблице 1.

Таблица 1

Морфобиохимические показатели крови молодняка гусей $(\overline{\mathrm{X}} \pm \mathrm{S} \overline{\mathrm{x}})$

\begin{tabular}{|l|l|l|l|}
\hline \multirow{2}{*}{ Показатель } & \multicolumn{2}{|l|}{ Группа } & \multicolumn{2}{|l|}{} \\
\cline { 2 - 4 } & контрольная & 1 опытная & 2 опытная \\
\hline Эритроциты, х $10^{12} / л$ & $2,26 \pm 0,06$ & $2,36 \pm 0,06$ & $2,54 \pm 0,05^{*}$ \\
\hline Лейкоциты, х $10^{9} / л$ & $20,02 \pm 0,50$ & $20,45 \pm 0,90$ & $21,86 \pm 0,83$ \\
\hline Гемоглобин, г/л & $124,48 \pm 1,89$ & $133,19 \pm 2,42$ & $134,51 \pm 2,31^{*}$ \\
\hline Щелочной резерв, мг\% & $704,38 \pm 9,36$ & $714,86 \pm 11,93$ & $762,18 \pm 10,76^{*}$ \\
\hline Общий белок, г/л & $56,83 \pm 2,46$ & $62,17 \pm 2,20$ & $62,08 \pm 2,38$ \\
\hline Общий азот, мг\% & $933,67 \pm 18,87$ & $986,88 \pm 17,64$ & $1016,22 \pm 16,78^{*}$ \\
\hline Кальций, ммоль/л & $2,68 \pm 0,18$ & $2,64 \pm 0,21$ & $2,51 \pm 0,16$ \\
\hline
\end{tabular}




\begin{tabular}{|l|l|l|l|}
\hline $\begin{array}{l}\text { Неорганический } \\
\text { фосфор, ммоль/л }\end{array}$ & $2,69 \pm 0,13$ & $2,35 \pm 0,11$ & $2,25 \pm 0,16$ \\
\hline
\end{tabular}

$* \mathrm{P}<0,05$

Исследованиями установлено, в контрольной группе количество эритроцитов было меньше, чем у аналогов остальных групп на 4,42 и 12,39\% (P<0,05) соответственно. Гусята 2 опытной группы превосходили сверстников из 1 опытной по количеству эритроцитов на 7,63\%. Гусята контрольной группы имели гемоглобина в среднем 124,48 г/л, что меньше по сравнению с опытными на 7,00 и $8,06 \%(\mathrm{P}<0,05)$ соответственно, что указывает на интенсивный рост молодняка данных групп.

Количество лейкоцитов у гусят, получавших добавку Витаммин, больше по сравнению с контрольными. Количество лейкоцитов в крови значительно увеличивается при более интенсивном обмене веществ, связанном с повышением продуктивности, а именно с приростом живой массы. Так, в 1 и 2 опытных группах количество лейкоцитов на 2,15 и 9,19\% соответственно больше, по сравнению с контрольной. Во 2 опытной группе количество лейкоцитов было больше на 6,89\%, по сравнению с 1 опытной группой. Некоторое увеличение количества лейкоцитов у гусят, получавших добавку Витаммин, указывает на усиление деятельности аппарата кроветворения, что связано с более интенсивным ростом птицы.

Содержание кальция в сыворотке крови гусят было наибольшим у контрольной группы - 2,68 ммоль/л, что на 1,49\% больше, чем в 1 опытной и - на 6,34\%, в сравнении со 2 опытной. Содержание неорганического фосфора в сыворотке крови было максимальным у гусят контрольной группы - 2,69 ммоль, что на 12,64\%больше, чем в 1 опытной, и на 16,36\%, в сравнении со 2 опытной.

Щелочной резерв в контрольной группе был меньше, чем в опытных на 1,49 и 8,21\% (Р<0,05) соответственно. Наибольший щелочной резерв отмечен у гусят 2 опытной группы, в сравнении с 1 опытной на 6,62\%.

Содержание общего азота в контрольной группе составило 933,67 мг\% и было меньше, чем в опытных на 5,70 и 8,84 (P<0,05) \% соответственно. Данный показатель в 1 опытной группе был меньше, чем во 2 опытной - на 2,97\%. 
Содержание общего белка у гусят контрольной группы было меньше, чем в опытных на 9,40 и 9,24\%. Содержание общего белка в 1 опытной группе было на 0,14\% меньше, по сравнению со 2 опытной. Полученные результаты свидетельствуют об активном протекании окислительно-восстановительных процессов в организме гусят опытных групп, что вероятно, связано с действием кормовой добавки Витаммин.

Фракционный состав белка сыворотки крови гусят представлен в таблице 2. Установлено, что у гусят контрольной группы на долю альбуминовой фракции приходилось на 5,63\% и 6,96\% (P<0,05), меньше в сравнении с опытными соответственно. При этом, у гусей 1 опытной группы данный показатель был меньше, чем у 2 опытной на 1,33\%. Глобулинов у гусят контрольной группы было больше, чем у опытных на $5,63 \%$ и 6,96\% (P<0,05) соответственно. У птицы 1 опытной группы данный показатель был больше, чем во 2 опытной на 1,33\%.

Таблица 2

Фракционный состав белка сыворотки крови гусят, \% $(\overline{\mathrm{X}} \pm \mathrm{S} \overline{\mathrm{x}})$

\begin{tabular}{|l|l|l|l|}
\hline \multirow{2}{*}{ Показатель } & \multicolumn{3}{|l|}{ Группа } \\
\cline { 2 - 4 } & контрольная & 1 опытная & 2 опытная \\
\hline Альбумины & $32,52 \pm 1,25$ & $38,15 \pm 1,57$ & $39,48 \pm 1,27^{*}$ \\
\hline Глобулины & $67,48 \pm 1,25$ & $61,85 \pm 1,57$ & $60,52 \pm 1,27 *$ \\
\hline$\alpha$-глобулины & $13,44 \pm 0,96$ & $18,10 \pm 2,65$ & $13,50 \pm 1,56$ \\
\hline$\beta$-глобулины & $11,78 \pm 1,62$ & $10,66 \pm 1,51$ & $10,15 \pm 1,04$ \\
\hline$\gamma$-глобулины & $47,70 \pm 2,71$ & $39,72 \pm 4,45$ & $46,92 \pm 0,87$ \\
\hline А/Г коэффициент & $0,45 \pm 0,01$ & $0,56 \pm 0,03 *$ & $0,56 \pm 0,02^{*}$ \\
\hline
\end{tabular}

$* \mathrm{P}<0,05$

На долю $\alpha$-глобулинов у гусят приходилось от 14,44 до 18,10\%, причем меньшее их количество отмечено у гусят контрольной группы: разница с 1 и 2 опытной 4,66 и 0,06\% соответственно. У птицы 1 опытной группы $\alpha$-глобулинов было больше, чем у сверстников из контроля на 4,66\%, из 2 опытной - на 4,60\%. $\beta$-глобулинов у гусят контрольной группы было больше, чем у аналогов из опытных на 1,12 и 1,63\%, а $\gamma$-глобулинов - на 7,98 и 0,78\% соответственно. Разница между опытными группами по содержанию $\beta$-глобулинов была больше у птицы 1 опытной группы на 0,51\%, чем во 2 опытной, а по содержанию $\gamma$-глобулинов 
больше у 2 опытной, чем в 1 опытной на 7,20\%. Альбумин-глобулиновый $(\mathrm{A} / \Gamma)$ коэффициент был наибольшим $(0,56)$ в опытных группах, или на $24,44 \%$ (P<0,05) в сравнении с контролем. Между опытными группами разницы по данному показателю не установлено, они были равны.

Таким образом, использование кормовой добавки Витаммин для гусей способствовало более интенсивному обмену веществ, и как следствие лучшее снабжение кислородом органов и тканей, в сравнении со сверстниками из контроля. Проведенные в наших исследованиях гематологические анализы подтверждают особенности обмена веществ у гусей, потреблявших добавку Витаммин. В опытных группах, при увеличении дозировки кормовой добавки Витаммин у гусят отмечено повышение уровня тканевого дыхания, что характерно при увеличении обменных процессов и как следствие, повышении продуктивности. Полученные результаты согласуются с мнением ученых, экспериментально установившими что использование различных кормовых добавок, в том числе витаминных, позволяет улучшить продуктивность и физиологические показатели птицы $[9 ; 10$; $11 ; 12 ; 13 ; 14 ; 15 ; 16]$.

\section{Список литературы}

1. Крылова С.А. Анализ состояния и перспективы развития мясного и яичного птицеводства / С.А. Крылова, Т.А. Лежнина // Аллея науки. - 2019. - Т.1. №11(38). - С. 298 - 301.

2. Булдакова Н.Д. Оценка реализации продуктивного потенциала цыплятбройлеров / Н.Д. Булдакова // Научные труды студентов Ижевской ГСХА. Ижевск: Изд-во Ижевская ГСХА, 2018. - С. 19 - 22.

3. Астраханцев А.А. Реализация потенциала продуктивности яичных и мясных кроссов кур в промышленном птицеводстве / А.А. Астраханцев, Н.П. Казанцева, Н.А. Санникова // Материалы Международной научно-практической конференции «Современному АПК - эффективные технологии». - Ижевск: Ижевская государственная сельскохозяйственная академия, 2019. - С. 40 - 45.

4. Hamdia J.F., Pérezb M., Létourneau-Montminya P., Franco-Rossellób R., Aliguec R., Solà-Oriolb D. The effects ofmicrobialphytases and dietary calcium and 
phosphorus levels on the productive performance and bone mineralization of broilers // Animal Feed Science and Technology - 2018. - №248. - P.41-51.

5. Widodo A.E., Nolan J.V. Response of Broiler Chickens to Triticale-Based Diets Supplemented with Microbial Enzymes // Poultry Science Journal - 2018. - №6. P. 25-40.

6. Ахметова Л. Влияние добавки Винивет на рост и развитие цыплят кросса «Конкурент-2» / Л. Ахметова [и др.]. // Птицеводство. - 2012. - №11. - С. 19-21.

7. Суханова С.Ф. Планирование и организация эксперимента. / С.Ф. Суханова, Г.С. Азаубаева, А.Г. Махалов. - Курган: Изд-во Курганская ГСХА, 2015. $210 \mathrm{c}$.

8. Суханова С.Ф. Биометрические методы в животноводстве / С.Ф. Суханова, Г.С Азаубаева, Т.Л. Лещук, А.Г. Кощаев. - Краснодар: КубГАУ, 2017. $162 \mathrm{c}$.

9. Азаубаева Г.С. Продуктивность гусынь родительского стада при использовании кормовой добавки Лив 52 / Г.С. Азаубаева, С.Ф. Суханова, В.К. Баскаев // Вестник Курганской ГСХА. - 2014. - №1 - С. 31 - 35.

10. Суханова С.Ф. Морфологические и биохимические показатели крови цыплят-бройлеров / С.Ф. Суханова, С.В. Кожевников // Кормление сельскохозяйственных животных и кормопроизводство. - 2009. - №1-2. - С. 46 - 50.

11. Суханова С.Ф., Кармацких Ю.А. Морфологические показатели у гусят, получавших бентонит / С.Ф. Суханова, Ю.А. Кармацких // Птицеводство. 2004. - №6. - C. 16 - 17.

12. Суханова С. Влияние пробиотических препаратов на биохимические показатели крови гусят-бройлеров / С. Суханова, С. Кожевников, С. Шульгин // Главный зоотехник. - 2012. - №4. - С. 55 - 57.

13. Суханова С.Ф. Авизим 1100 в составе кормосмесей для гусят-бройлеров / С.Ф. Суханова, А.Г. Махалов // Кормление сельскохозяйственных животных и кормопроизводство. - 2008. - №4. - С. 39 - 43. 
14. Кожевников С.В.Биологически активные вещества в кормах для цыплят-бройлеров / С.В. Кожевников, С.Ф. Суханова // Зоотехния. - 2010. - №4. C. $16-17$.

15. TemiraevR.B., SukhanovaS.F., TarchokovT.T., OsepchukD.V., BaevaZ.T., KubatievaZ.A., KozhokovM.K., KaloevaZ.Yu., KhmelevskayaA.V.Effect of adsorbents in diets on production efficiency of broiler with high nutritional and ecological characteristics //Journal of livestock science. - Vol. 11, number 1. - 2020. - pp. 2632. (DOI 10.33259/JLivestSci.2020.26-32)

16. Sukhanova S. F., Kurskaya Yu. A., Bischokov R. M., Temiraev R. B. Exchange processes in the organism of goslings of different ages feeding with seleniumcontaining fodder supplement // International Conference on World Technological Trends in Agribusiness: IOP Conf. Series: Earth and Environmental Science 624 (2021) 012096. - IOP Publishing. doi:10.1088/1755-1315/624/1/012096

\section{References}

1. Krylova, S. A., \& Lezhnina, T. A. (2019). Analiz sostoianiia i perspektivy razvitiia miasnogo i iaichnogo ptitsevodstva. Alleia nauki, T.1, 11(38), 298-301.

2. Buldakova, N. D. (2018). Otsenka realizatsii produktivnogo potentsiala tsypliat-broilerov. Nauchnye trudy studentov Izhevskoi GSKhA, 19-22. Izhevsk: Izd-vo Izhevskaia GSKhA.

3. Astrakhantsev, A. A., Kazantseva, N. P., \& Sannikova, N. A. (2019). Realizatsiia potentsiala produktivnosti iaichnykh i miasnykh krossov kur v promyshlennom ptitsevodstve. Materialy Mezhdunarodnoi nauchno-prakticheskoi konferentsii "Sovremennomu APK, effektivnye tekhnologii", 40-45.

4. Hamdia, J. F., Perezb, M., Letourneau-Montminya, P., Franco-Rossellob, R., Aliguec, R., \& Sola-Oriolb, D. (2018). „,, The effects ofmicrobialphytases and dietary calcium and phosphorus levels on the productive performance and bone mineralization of broilers. Animal Feed Science and Technology, 248, 41.

5. Widodo, A. E., \& Nolan, J. V. (2018). Response of Broiler Chickens to Triticale-Based Diets Supplemented with Microbial Enzymes. Poultry Science Journal, 6, 25. 
6. Akhmetova, L. (2012). Vliianie dobavki Vinivet na rost i razvitie tsypliat krossa "Konkurent-2". Ptitsevodstvo, 11, 19-21.

7. Sukhanova, S. F., Azaubaeva, G. S., \& Makhalov, A. G. (2015). Planirovanie i organizatsiia eksperimenta., 210. Kurgan: Izd-vo Kurganskaia GSKhA.

8. Sukhanova, S. F., Leshchuk, T. L., \& Koshchaev, A. G. (2017). Biometricheskie metody v zhivotnovodstve., 162. Krasnodar: KubGAU.

9. Azaubaeva, G. S., Sukhanova, S. F., \& Baskaev, V. K. (2014). Produktivnost' gusyn' roditel'skogo stada pri ispol'zovanii kormovoi dobavki Liv 52. Vestnik Kurganskoi GSKhA, 1, 31-35.

10. Sukhanova, S. F., \& Kozhevnikov, S. V. (2009). Morfologicheskie i biokhimicheskie pokazateli krovi tsypliat-broilerov. Kormlenie sel'skokhoziaistvennykh zhivotnykh i kormoproizvodstvo, 1, 46-50.

11. Sukhanova, S. F., \& Karmatskikh, Iu. A. (2004). Morfologicheskie pokazateli u gusiat, poluchavshikh bentonit. Ptitsevodstvo, 6, 16-17.

12. Sukhanova, S., Kozhevnikov, S., \& Shul'gin, S. (2012). Vliianie probioticheskikh preparatov na biokhimicheskie pokazateli krovi gusiat-broilerov. Glavnyi zootekhnik, 4, 55-57.

13. Sukhanova, S. F., \& Makhalov, A. G. (2008). Avizim 1100 v sostave kormosmesei dlia gusiat-broilerov. Kormlenie sel'skokhoziaistvennykh zhivotnykh $i$ kormoproizvodstvo, 4, 39-43.

14. Kozhevnikov, S. V., \& Sukhanova, S. F. (2010). Kozhevnikov S.V.Biologicheski aktivnye veshchestva v kormakh dlia tsypliat-broilerov. Zootekhniia, 4, 16-17.

15. (2020). TemiraevR.B., SukhanovaS.F., TarchokovT.T., OsepchukD.V., BaevaZ.T., KubatievaZ.A., KozhokovM.K., KaloevaZ.Yu., KhmelevskayaA.V.Effect of adsorbents in diets on production efficiency of broiler with high nutritional and ecological characteristics. Journal of livestock science, Vol. 11, number 1, 26. doi:10.33259/JLivestSci.2020.26-32

16. Sukhanova, S. F., Kurskaya, Yu. A., Bischokov, R. M., \& Temiraev, R. B. , Exchange processes in the organism of goslings of different ages feeding with selenium-containing fodder supplement. International Conference on World 
Technological Trends in Agribusiness: IOP Conf. Series: Earth and Environmental Science 624 (2021) 012096, IOP Publishing. doi:10.1088/1755-1315/624/1/012096

Гришин Евгений Алевтинович - аспирант, ФГБОУ ВО «Курганская государственная сельскохозяйственная академия имени Т.С.Мальцева», Курган, Россия.

Grishin Evgenii Alevtinovich - postgraduate student, FSBEI of HE "Kurgan State Agricultural Academy by T.S. Maltsev", Kurgan, Russia. 